\title{
THE APPLICATION OF THE CHARTER OF FUNDAMENTAL RIGHTS OF THE EU BY THE GERMAN FEDERAL CONSTITUTIONAL COURT WITH REFERENCES TO THE OTHER FEDERAL COURTS
}

\author{
RAINER ARNOLD, LUKAS CERNY
}

\begin{abstract}
:
The German Federal Constitutional Court (FCC) applies the Charter of Fundamental Rights of the EU (ChFR) if German law is "determined" by EU law. The interpretation of article 51.1 ChFR which regulates the applicability of the ChFR is narrower than that of the Court of Justice of the EU. The FCC which has recognized, with some reservations, the primacy of supranational over national constitutional law maintains its concept of constitutional identity defined according to the intangibility clause of article 79.3 Basic Law (BL). If human dignity (article $1 \mathrm{BL}$ and the fundamental State structures as enumerated by article $20 \mathrm{BL}$ ) are concerned, the FCC does not apply the ChFR regardless of article 51.1FCh but the identity concept. Overall, the references of the FCC to the ChFR are relatively scarce.
\end{abstract}

Keywords: constitutional identity; application of the Charter of Fundamental Rights of the EU; primacy of supranational law; human dignity; intangibility clause; fundamental State structures

Klíčová slova: ústavní identita; aplikace Listiny základních práv EU; nadřazenost nadstátního práva; lidská důstojnost; klauzule věčnosti; základní složky státu

DOI: $10.14712 / 23366478.2018 .34$

\section{INTRODUCTION}

The Charter of Fundamental Rights of the EU, the basic text for the protection of the individual against the supranational power, has binding force for the institutions of the EU as well as for the member states when they execute EU law. In this latter case the rights of the Charter and not those of the national Constitution have to be applied. The present study has the intention to clarify whether the constitutional courts comply with this obligation.

The following article investigates the judicial practice of the German Federal Constitutional Court (FCC). For better understanding the context, a short introduction into structure and competences of the FCC and an overview of the previous EC/EU related constitutional jurisprudence are given.

The German Federal Constitutional Court (FCC) has been established in 1951 and is composed of two Chambers (called "Senate"), each of them with eight judges, elected for 12 years (without being reeligible) half by the Federal Parliament and half by the 
Federal Council. Decisions of the FCC are made by each of the two Chambers according to the competences which are shared between them.

The competences of the FCC are large: the core competence is the review of legislation either in an abstract (Art. 93.1 no. 2 Basic Law, BL) or in a concrete form (Art. 100.1 BL). Federal Government, one of the 16 member states governments or one quarter of the members of Federal Parliament can initiate the abstract review against all types of law (federal or member states law) in order to ensure their conformity with the constitution. The concrete review is initiated by a tribunal which is convinced that a formal law they have to apply in a concrete case is unconstitutional.

The most frequent remedy is the individual constitutional complaint which is examined by the FCC only if it is admitted, regularly by a three judges commission examining whether the complaint is important for the development of constitutional law or the concerned person would otherwise suffer and irreparable loss. Only about 2 to $3 \%$ of the yearly about 6000 complaints are not refused a limine. Such a complaint is possible against every public law act (executed action, judicial decision or legislation), within the delay of one month or, in case of legislation, of one year, presupposed that the complainant is directly and individually concerned in one of his/her fundamental rights (or other rights enumerated by article 93.1 no. $4 \mathrm{a} \mathrm{BL}$ ). The complaint is a subsidiary what means that all regular remedies must have been exhausted.

Disputes between the supreme State institutions (Federal Parliament, Federal Government, Federal President) or parts of them (Parliamentary group, single deputy, per tradition also political parties, etc.) on their functions can address the FCC (Art. 92.1 no. 1 BL). Also federal controversies between Federation and member states or between member states themselves can be presented to the FCC for decision (Art. 93.1 no. 3 and $4 \mathrm{BL}$ ). Legislation can attribute specific judicial competences the FCC. Political parties can be prohibited by the FCC if they combat the free democratic order guaranteed by the BL.

The FCC has rendered numerous decisions in the field of European integration. The basis for such a judicial activity is preponderantly article 23 (formerly 24.1) BL, the constitutional integration norm which allows the federal parliament to transfer sovereign powers ("Hoheitsrechte") to the supranational institutions. This corresponds to the preamble of the BL which states the integration of Germany into the European and international communities as a basic objective for the State as well as to the concept of "open statehood" ("offene Staatlichkeit").

As the FCC reviews only German law under its compatibility with the BL, the basis for integration-related jurisprudence is the German Act of approval to the integration treaties adopted by the Federal Parliament in cooperation with the Federal Council. The FCC examines through this Act which contains the "integration program"1 the compatibility of supranational actions with the integration treaties. A direct review of supranational acts which are regarded as autonomous, because they result from a separate legal order is not carried out by the FCC except in cases of ultra vires.

The position of the FCC is in favor of European integration, however, three reservations have been made. While the FCC has early recognized the main attributes of the su-

FCC vol. 89, p. 155. 
pranational legal order as mainly formulated by the Costa/ENEL physician of the Court of Justice of the EU (CJEU) such as primacy of supranational law, its direct applicability and other attributes ${ }^{2}$, it has confirmed three conditions which must be fulfilled: (1) The guarantee of fundamental rights must be adequately realized on the supranational level; (2) the supranational actions must not be ultra vires, and (3) the constitutional identity must not be affected by supranational law. This corresponds essentially also the new text of the integration norm of article 23.1 BL which has been introduced in 1993, with regard to the establishment of the EU.

The fundamental rights issue had arisen because EEC law was applied by a German authority. The question was which legal order protects the concerned persons by fundamental rights, the German BL because a German authority was acting or the community order which has adopted the law to be applied. This question was resolved by the Solange jurisprudence (Solange I in 1974², Solange II in 19864). While in 1974 preference was given for the lack of supranational fundamental rights, to the German rights, in 1986 the existence of judge-made general principles protecting individual was regarded as substantively and functionally equivalent to the BL and therefore applicable instead of the national guarantees. Under the condition that fundamental rights will be adequately protected at the supranational level also in the future the primacy of supranational fundamental rights is recognized. If the protection would essentially lower, the FCC which decides on the question of protection quality would apply again the German fundamental rights. This is in principle also the position of today of the FCC. With the entrance into force of the Charter of Fundamental Rights of the EU (ChFR) this high-level protection is firmly guaranteed. This fundamental rights reservation which has been confirmed in the later jurisprudence is now to some extent relativized by the identity reservation (see below).

The second reservation of the FCC is a prohibition for the supranational institutions to act "ultra vires", that means beyond the competences attributed to them by the member states in the integration treaties. This has essentially been elaborated in the Maastricht judgment ${ }^{5}$ and has been mitigated in the Mangold ${ }^{6}$ decision. The supranational act must be obviously beyond the attributed competence and entail a serious shift within the competence distribution between EU and member states. The FCC is obliged to ask the CJEU for the interpretation of the concerned act in preliminary question proceedings, however the FCC reclaims the final word.

The third reservation is the most important. In its decision on the constitutionality of the Lisbon Treaty ${ }^{7}$ the FCC denies the primacy of EU law over the core elements of the German constitution which for the so-called constitutional identity. The FCC refers for the definition to article $79.3 \mathrm{BL}$ (to which article $23 \mathrm{BL}$ refers), the eternity clause ${ }^{8}$,

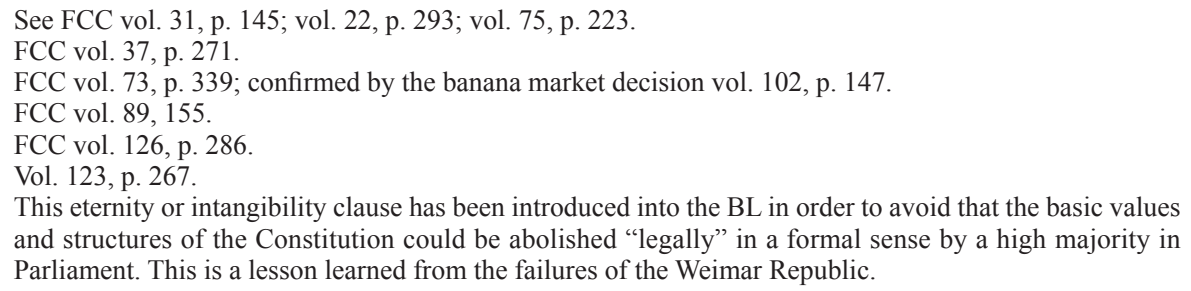
and structures of the Constitution could be abolished "legally" in a formal sense by a high majority in Parliament. This is a lesson learned from the failures of the Weimar Republic. 
which says that constitutional reform can never eliminate or essentially change human dignity (Art. $1 \mathrm{BL}$ ) and the principles named in article 20 BL: democracy, Republic, federalism, social State. The FCC reclaims the exclusive competence to interpret constitutional identity and to forbid the application of EU law in Germany if it is an ultra vires act or affects constitutional identity.

\section{THE DIFFERENT MODES OF HOW THE FEDERAL CONSTITUTIONAL COURT APPROACHES THE CHARTER OF FUNDAMENTAL RIGHTS OF THE EU}

The major constellations in which the FCC can deal with the ChFR are: (1) to apply or disapply the ChFR by affirming or denying its applicability in accordance with article 51.1 ChFR or even to disapply the ChFR without considering article 51.1 ChFR. (2) to disapply the ChFR for reasons of alleged primacy of national constitutional law over EU law, in particular with reference to the national constitutional identity defined on the basis of article 79.3 BL, (3) to apply the ChFR only indirectly by interpreting national fundamental rights (as criteria of control) or national legislation (as object of control) in the light of the ChFR.

It shall be mentioned that the ChFR is not directly a criterion for the review carried out by the FCC. However, a provision of the national constitution, specifically a fundamental right of the $\mathrm{BL}$ (in practice often article 101.1 BL) is the relevant review criterion for the FCC but the argumentation in the context of this review involves the reference to the ChFR.

On the basis of this categorization the FCC jurisprudence shall be analyzed and evaluated.

\section{THE TYPES OF DECISIONS IN WHICH THE FCC REFERS (OR CAN REFER) TO THE CHFR}

The FCC may be confronted with the ChFR in all decisions:

(a) in ordinary decisions of one of the two Chambers (Senate), ${ }^{9}$

(b) in a three judges decision which declares an individual complaint (Verfassungsbeschwerde) as successful, according to s. $93 \mathrm{c}$ FCCAct, ${ }^{10}$

\footnotetext{
9 BVerfG, Order of the Second Senate of 15 December 2015 - 2 BvR 2735/14 - paras. (1-126), http:// www.bverfg.de/e/rs20151215 2bvr273514en.html; VerfG, Order of the Second Senate of 19 December 2017 - 2 BvR 424/17 - paras. (1-60), http://www.bverfg.de/e/rs20171219_2bvr042417en.htm; BVerfG, Order of the Second Senate of 19 December 2017 - 2 BvR 424/17 - paras. (1-60), http://www.bverfg.de /e/rs20171219_2bvr042417en.html; BVerfG, Beschluss des Zweiten Senats vom 21. April 2015 - 2 BvR 1322/12 - Rn. (1-94), http://www.bverfg.de/e/rs20150421_2bvr132212.html; BVerfG, Judgment of the First Senate of 24 April 2013 - 1 BvR 1215/07 - paras. (1-233), http://www.bverfg.de/e/rs20130424 1 bvr121507en.html.

10 B VerfG, Beschluss der 2. Kammer des Zweiten Senats vom 09. November 2016 - 2 BvR 545/16 - Rn. (1-51), http://www.bverfg.de/e/rk20161109_2bvr054516.html.
} 
(c) in a three judges decision which refuses to admit an individual complaint (and is motivated), according to.s.93b FCCAct, ${ }^{11}$

(d) in a resolution to raise a preliminary question to the Court of Justice of the EU according to Art. 267 TFEU, 12

(e) in a decision on an interim decision, according to s. 32 FCCAct. ${ }^{13}$

\section{THE DIVERGING INTERPRETATION OF ARTICLE 51.1 CHFR: FCC V. CJEU}

The ChFR which entered into force in 2009, is a part of EU primary law and therefore enjoys primacy over the law of the member States. The ChFR itself determines to whom it is addressed: to the "institutions, bodies, offices and agencies of the Union" as well as to the member States "only" "when they are implementing Union law". This determination of the ChFR's field of application also defines the reach of its primacy. The relation between Charter and national constitution is an alternative one.

The crucial question is how to understand the applicability clause of article 51.1 ChFR. This is connected to the question which legal order, the supranational or the national order, has the competence to define ultimately the clause of applicability. Article 51.1 ChFR is part of EU law, it has to be interpreted with the methodology inherent to EU law, in its finality context and by the competent EU institution, that is the Court of Justice of the EU. The fact that this clause delimits two legal orders raises problems whether such a delimiting clause excludes the definition competence of the other legal order. The result could be that two courts, the Court of Justice of the EU of the one side and the FCC on the other side reclaim the power to define. The consequence can be and are diverging interpretations of the same provision.

As explained above article 51.1 ChFR is the application clause of the Charter which determines under which conditions the ChFR is applicable for the member States. The principle of EU law primacy comes into effect insofar as the Charter is applicable. It is inherent in the primacy concept that the application clause as a part of EU primary law has to be understood in the sense of the interpretation made by the institution which is

11 BVerfG, Beschluss der 1. Kammer des Zweiten Senats vom 14. Dezember 2017 - 2 BvR 1872/17 Rn. (1-34), http://www.bverfg.de/e/rk20171214_2bvr187217.html; BVerfG, Beschluss der 2. Kammer des Zweiten Senats vom 15. Dezember 2011 - 2 BvR 148/11 - Rn. (1-47), http://www.bverfg.de/e /rk20111215 2bvr014811.htm; BVerfG, Beschluss der 3. Kammer des Ersten Senats vom 29. Mai $2012-$ 1 BvR 3201/11 - Rn. (1-40), http://www.bverfg.de/e/rk20120529_1bvr320111.html; BVerfG, Beschluss der 2. Kammer des Ersten Senats vom 15. Oktober 2015 - 1 BvR 2329/15 - Rn. (1-14), http://www.bverfg .de/e/rk20151015_1bvr232915.html; BVerfG, Beschluss der 2. Kammer des Ersten Senats vom 27. Juni 2014 - 1 BvR 1313/14 - Rn. (1-13), http://www.bverfg.de/e/rk20140627_1bvr131314.html; BVerfG, Beschluss der 3. Kammer des Ersten Senats vom 26. März 2014 - 1 BvR 3185/09 - Rn. (1-42), http://www .bverfg.de/e/rk20140326_1bvr318509.html; BVerfG, Beschluss der 2. Kammer des Ersten Senats vom 10. August 2017 - 1 BvR 1803/15 - Rn. (1-23), http://www.bverfg.de/e/rk20170810_1bvr180315.htm.

12 In some of the relevant FCC decisions the obligation to raise a preliminary question was taken into consideration but was not affirmed for the inapplicability of the ChFR: see BVerfG, Judgment of the First Senate of 24 April 2013 - 1 BvR 1215/07 - paras. (1-233), http://www.bverfg.de/e/rs20130424_1bvr121507en .html.

13 See https://datenbank.nwb.de/Dokument/Anzeigen/705730/. 
competent for the interpretation of EU primary law, ultimately the Court of Justice of the EU. However, the FCC assumes the competence to interpret the application clause by its own without discussing explicitly the competence attribution issue. This is in line of the FCC's basic position that it is the State's exclusive and for reasons of sovereignty not transferable competence to define how far EU law reaches and where national law ends. This is ultimately the position of the FCC confirmed in its ultra vires jurisprudence in the Maastricht ${ }^{14}$ and Lisbon Treaty ${ }^{15}$ decisions.

In the FCC decision of April 24, $2013^{16}$ concerning the anti-terror register and specifically the question whether the collection and transfer of data collected from different security institutions on terrorist activities and networks to the police is compatible with the German constitution. In this context the question of the applicability of the ChFR and with this the question of the necessity of a preliminary question to the Court of Justice of the EU on the interpretation of Charter rights arose. The FCC confirmed the constitutionality of the data collection in case that the transfer of the data to the police is exceptional. However, the court denied the applicability of the ChFR and the necessity for a preliminary question procedure.

The FCC interprets the applicability clause of the Charter in a way which is much stricter than what is pointed out by the Court of Justice of the EU, especially in the case Akerberg Fransson, one (not the only!) of the judgments of the Court of Justice of the EU in which the applicability of the EU Charter is specified. ${ }^{17}$

The FCC argues that the EU Charter is only applicable instead of the constitutional law of a Member State if the national provisions in question are "determined" by EU law (in the English version of the decision, as translated by the court: is ... "governed by Union law") ${ }^{18}$, otherwise there is no "execution of EU law" (in the English version: ... "not a case of implementation of European Union law") which would make applicable the ChFR. ${ }^{19}$

The FCC pointed out that the connection between the national provision and the field of application of EU law must be a concrete one, an abstract connection in that sense cannot be regarded as sufficient for the application of the ChFR. The same is said for purely factual impacts of EU law on member States law.

The approach of the Court of Justice of the EU in the mentioned case Akerberg Fransson is criticized by the FCC according to this view.

As to the wording of article 51.1 of the ChFR we have to state that the various versions are not free from certain divergences: as a condition for the Charter application in the field of the member States law is formulated in the English version: ... "when they are implementing union law" (formulation which is referred to by the FCC in

14 FCC vol. 89, p. 155, CI3.

15 http://www.bverfg.de/e/es20090630_2bve000208en.html: BVerfG, Judgment of the Second Senate of 30 June 2009 - 2 BvE 2/08, paras. 240, 241, 334, 338-340, 347.

16 BVerfG (FCC) vol. 133, p. 277-377 and http://www.bvefg.de/e/rs20130424_1bvr121507.html (in English: ECLI:DE:BVerfG:2013:rs20130424.1bvr121507).

17 C-617/10 Akerberg Fransson, ECLI:EU:C:2013:105.

18 The FCC makes reference, at this remark, to the FCC decisions vol. 118, p. 79, 95; vol. 121, p. 1, 15; vol. 125 , p. 260, 306-307; vol. 129 , p. 78, 90-91.

19 Para. 88 of the internet text of the decision. 
the English translation of the judgment which speaks of "implementation", while the German authentic text uses the word "determiniert", what means "determined (by EU law)"). The French text of article 51.1 of the Charter uses the formula "mettre en oeuvre le droit de l'Union", which can be understood in a larger sense such as "realization", "concretization" of EU law, which opens a broader field of application. The Spanish and Portuguese texts speak of "cuando apliquen/apliquem" EU law, using therefore a word the sense of which is more narrow than the above mentioned formulations. To "apply" (as used in these texts) means to transform an already existing law on the EU side into existence. By this formula a less creative and discretionary power is given to the member State. In the Italian version the text uses the term "attuazione", which is larger than "applicazione, esecuzione".

We can state that the text versions of article 51.1 ChFR are rather diverging and do not completely support neither the approach of the Court of Justice of the EU nor that of the FCC.

\section{ANALYSIS AND EVALUATION OF THE RELEVANT JURISPRUDENCE OF THE FCC}

\subsection{GENERAL EVALUATION}

German constitutional jurisprudence is not rich of references to the ChFR. The basic decision of the FCC is that on the interpretation of article 51.1 ChFR rendered in 2013 which presented a stricter perspective than that that of the Court of Justice of the EU. This position is still valid and has been confirmed (with the short argumentation) in a later decision. ${ }^{20}$

Only a few decisions with major relevance to the ChFR have been rendered by one of the Chambers (Senate) while most of those that make reference to the ChFR (reference which is often of a relatively marginal character) are decisions of a three judges commission ("Kammer"), regularly refusing the admittance of a constitutional complaint. It is evident that the legal authority of the three judges decision is not as high as that of a Court's (Chamber's, Senate's) decision which has binding force on all public authorities according to s. 31 FCC Act and in case of legislation review even the force of law. However, declaring an individual complaint successful by three judges according to s.93c.1 FCC Act is equivalent to a regular court's decision and can have, as experience demonstrates, important impact. In this context we can refer to the mentioned decision of November 9, 2016 ${ }^{21}$ which applies the German fundamental rights but confirms the conceptual basis of the FCC's interpretation of article 51.1 ChFR.

It shall be mentioned that the decided cases, particularly those connected with an individual complaint, do not end up with a decision affirming or denying a Charter right

20 BVerfG, Beschluss der 2. Kammer des Zweiten Senats vom 09. November 2016 - 2 BvR 545/16 - Rn. (1-51), http://www.bverfg.de/e/rk20161109_2bvr054516.html.

21 VerfG, Beschluss der 2. Kammer des Zweiten Senats vom 09. November 2016 - 2 BvR 545/16 - Rn. (1-51), http://www.bverfg.de/e/rk20161109_2bvr054516.htm. 
but with a decision on a fundamental right (or another provision) of the BL. Frequently article 101.1 BL guaranteeing the lawful judge is in question, specifically in case of a complaint that a court of instance did not initiate a preliminary question procedure according to article $267 \mathrm{TFEU}$ and has, for that reason, violated article 101.1 BL. This issue is connected the ChFR insofar as in case of the applicability of the ChFR the court of instance (if a last instance court) would have been obliged to address the Court of Justice of the EU.22 The failure to do so is often regarded as a violation of the lawful judge guarantee what is, however, accepted by the FCC only under specific conditions. ${ }^{23}$ The FCC's argumentation considers necessarily the question whether the ChFR is applicable and therefore possible object of a preliminary question procedure. The case of article 101.1 BL clearly demonstrates that the Charter rights which cannot be directly invoked by an individual complaint are indirectly involved in this type of remedy.

Furthermore, the relation between article $51.1 \mathrm{ChFR}$ and the constitutional identity concept developed by the FCC is of high importance. The reference of the FCC to the identity clause of article $79.3 \mathrm{BL}$ is, in the perspective of the FCC, a limit to the impact of EU law and supersedes the ChFR no matter whether it is applicable or not.

\subsection{SPECIFIC EVALUATION OF THE DIFFERENT FCC DECISIONS}

As pointed out above the FCC's perspective on how to interpret article 51.1 ChFR as developed in the judgment of April 24, $2013^{24}$ has become relevant also to the subsequent jurisprudence. Indeed, the execution of the European arrest warrant is regarded as an "implementation" of EU law which "determines" (the decisive term used by the FCC) the process of extradition. Furthermore, the implementation of directives is to be regarded as being determined by EU law, at least as far as the directive prescribes the implementation in a strict sense and does not leave any discretionary power to the member states.

The jurisprudence of the FCC is rather scarce, as to the number of decisions and, notwithstanding some exceptions, as to depth and comprehensiveness of the argumentation.

In a case of asylum procedure (transfer to Italy in the context of a Dublin-III-procedure $)^{25}$ a reference to article $4 \mathrm{ChFR}$ has been made in the framework of an individual complaint based on a violation of efficient judicial protection according to article 19.4 BL. However, the complainant's argumentation was not regarded as sufficiently substantive for stating a violation of article $4 \mathrm{ChFR}$; the FCC refused to admit the constitutional complaint. It shall be noted that the complaint could not invoke, what the FCC has repeatedly stated, fundamental rights of the Charter but only German fundamental

\footnotetext{
22 In absence of the exceptions indicated by the CILFIT jurisprudence (C-283/81 CILFIT, ECLI:EU:C:1982:335).

23 FCC vol. 126, p. 286, 316-317.

24 See note 15.

25 BVerfG, Beschluss der 1. Kammer des Zweiten Senats vom 14. Dezember 2017 - 2 BvR 1872/17 - Rn. (1-34), http://www.bverfg.de/e/rk20171214_2bvr187217.html, para. 25.
} 
rights. ${ }^{26}$ However, the FCC has not denied the applicability of the Charter but recognized, at least indirectly, the applicability of article $4 \mathrm{ChFR}$ which was referred to in the decision jointly with article 3 of the Convention for the Protection of Human Rights and Fundamental Freedoms.

In a second decision ${ }^{27}$ (concerning the principle of ne bis in idem, article $50 \mathrm{ChFR}$, and the alleged failure to make a preliminary question to the EU CJ violating article 101.1 BL) the three judges commission also refused the admittance of an individual complaint referring, in this context, to the application clause of article 51.1 ChFR. The above-mentioned interpretation of this provision as already made by the FCC has been confirmed. As the inferior courts have declared the Charter applicable, the FCC regards, in this case, this interpretation by the inferior courts as reasonable. The FCC regarded the position of the inferior courts affirming the applicability of the ChFR as acceptable on the basis of the argument that the obligation of the courts to examine the provisions of the Schengen execution agreement, specifically of its article 54, can be considered as an obligation being "determined" by EU law. By this, the FCC has confirmed its own concept of the understanding of article $51.1 \mathrm{ChFR}$.

The decision of the FCC of December 15, $2015^{28}$ (concerning the extradition of an American citizen to Italy) is of high importance by introducing the constitutional identity concept and considering the relation of this concept with the application of the ChFR. The FCC starts its argumentation with the clear statement that constitutional identity must be ensured with respect to EU law and EU determined national law ${ }^{29}$. This statement clearly shows that within the reach of the constitutional identity concept the ChFR even if it is applicable seen from article 51.1 ChFR in the perspective of the FCC (as in the case of EU determined national law) is not applied by the FCC. While constitutional identity is explained as a concept which limits primacy of EU law and is justified despite the German constitutional law principle of "open statehood", the argumentation in its essential parts is not based on the applicability of the ChFR. There is in the first part of the decision a marginal and quite general remark ${ }^{30}$ on the fundamental rights protection in the EU, to article $6 \mathrm{TEU}$ and the ChFR which has no connection to the concrete case. Later the FCC points out that the European arrest warrant and the implementing German legislation have to be interpreted in the light of article $1.1 \mathrm{BL}$ as well as in the light of the ChFR. Article 51.1 GRCh is mentioned as a general characterization of the fundamental rights orientation of the $\mathrm{EU}^{31}$ The principle of mutual confidence which is at the basis of the European arrest warrant requires an equivalent rights protection in the member States and the EU. The court comes back, after this general statements on the high level of the fundamental rights protection in the $\mathrm{EU}$, to the overriding criterion

26 BVerfG, Beschluss der 2. Kammer des Ersten Senats vom 15. Oktober 2015: 1BvR2329/15, three judges decision of October 15, 2015.

27 BVerfG, Beschluss der 2. Kammer des Zweiten Senats vom 15. Dezember 2011 - 2 BvR 148/11 - Rn. (1-47), http://www.bverfg.de/e/rk20111215_2bvr014811.html.

28 BVerfG, Order of the Second Senate of 15 December 2015 - 2 BvR 2735/14 - paras. (1-126), http://www .bverfg.de/e/rs20151215_2bvr273514en.html.

29 Note $27 /$ para. 36.

30 Para. 46 of the text (note 27).

31 Para. 73; see also para. 81 and para. 82 referring to the Melloni case (C-399/11 Melloni, ECLI:EU: C:2013:107). 
of article $1.1 \mathrm{BL}$ as an element of constitutional identity. ${ }^{32}$ However, the court stresses that the direct application of the constitutional identity concept is not necessary in this case because the framework decision on the European arrest warrant can be interpreted, in the light of EU law and the ChFR, in such way that the protection required by article $1.1 \mathrm{BL}$ is fulfilled. 33

This resolves the problem in this concrete case but it gets quite clear that the FCC does not apply a priori the ChFR within the scope of constitutional identity defined through article 79.3 BL which particularly covers human dignity, article 1.1 BL. The court says that the member States have to observe the fundamental rights of the EU and in particular the ChFR when executing the arrest warrant but that these rights also have a significant interpretation impact on the arrest warrant system. ${ }^{34}$ The FCC states that the framework decision on the European arrest warrant corresponds in this interpretation to the requirements of article $1.1 \mathrm{BL}^{35}$ The execution of the arrest warrant by Germany as a member State must be clearly compatible with article $1.1 \mathrm{BL}$, therefore with the constitutional identity concept. ${ }^{36}$ As the principle of individual guilt is considered by the consolidated jurisprudence of the FCC as an essential part of human dignity, this is the decisive criterion in the concrete case. The interpretation of the framework decision on the European arrest warrant is effectuated through the impact of EU law and the $\mathrm{ChFR}$, and the execution of the arrest warrant must be compatible with constitutional identity. In the concrete case, the extradition was not permitted by the FCC because according to the relevant Italian criminal procedure law the facts of the committed crime would not have been examined after the extradition by the competent Italian court.

As a conclusion it can be said that the FCC gives priority clearly to the constitutional identity idea and insofar as not to the ChFR. However the interpretation of the legal basis for the execution of the arrest warrant is effectuated by the impact of supranational law.

The decision of the FCC of December 19, $2017^{37}$ is one of the rather rare decisions which the declares that article 101.1 BL has been violated by the failure of the court of instance to address the Court of Justice of the EU by a preliminary question, in the context of an extradition based on European arrest warrant of the person to Romania. The person in question had raised a constitutional complaint, with reference to the guarantee of human dignity by article $1.1 \mathrm{BL}$, concerning the Romanian conditions of detention in prison. The FCC states in this context that the court of instance should have raised a preliminary question for getting explained by the Court of Justice of the EU how to understand article $4 \mathrm{ChFR}$ which is applicable for the reason that the extradition procedure under the European arrest warrant is a process "determined" by EU law what leads to the application of the ChFR according to article 51.1 ChFR in the perspective of the FCC. The court of instance (the regional superior court of Hamburg) has not sufficiently

32 Para. 83.

33 Para. 84. See also paras. 91 and 92.

34 Paras. 92 and 94.

35 Para. 107.

36 Paras. 110, 113.

37 BVerfG, Order of the Second Senate of 19 December 2017 - 2 BvR 424/17 - paras. (1-60), http://www .bverfg.de/e/rs20171219_2bvr042417en.html. 
explained in its argumentation why there was no need for a preliminary question; article $4 \mathrm{ChFR}$ and article 3 of the Convention for the Protection of Human Rights and Fundamental Freedoms were declared as being quite clear in their dimensions concerning the conditions of imprisonment. Thus the court of instance did not use in an unacceptable way the preliminary question procedure. This was stated by the FCC as being a violation of the lawful judge guarantee of article 101.1 BL.

In conclusion it can be stated that the FCC's decision confirmed the application of the ChFR according to the perspective of the FCC as described above and applied article $4 \mathrm{ChFR}$.

In the three judges decision of March 26, $2014^{38}$ it was stated that the application of the ChFR, in the concrete case of article 28 of the ChFR, is only given if the EU has a substantive competence in the corresponding field. This was denied for the field of the right of coalition, right of strike and right of lock out in view of article 153.5 TFEU. 39

In further decisions the FCC refers to the ChFR for interpreting German constitutional law (in the concrete case article 33.2 BL). While this decision is only based on the BL the argumentation as such makes clear reference to EU law (the prohibition of discrimination for age) including article 21.1 ChFR. ${ }^{40}$

In the three judges decision of August 10, $2017^{41}$ the ChFR is not substantially applied because the complaint is not accepted a priori for lack of legitimate interest for raising a constitutional complaint. However, as the decision underlines, the provisions of the $\mathrm{BL}$, in the concrete case article $9.3 \mathrm{BL}$, have to be interpreted in the light of the supranational law, in the concrete case especially of article $28 \mathrm{ChFR}$ as the complainants have put forward.

\subsection{THE CHFR MENTIONED BY THE PARTIES /PARTICIPANTS WITHOUT BEING REFERRED TO BY THE FCC}

There are rather many cases in which parties/participants refer to the ChFR but the FCC does not mention it in its argumentation. ${ }^{42}$

\subsection{FURTHER CASES}

In the three judges decision of May $18,2016^{43}$ the ChFR which is mentioned by the complainant is not referred to in the argumentation of the decision because the fundamental rights of the BL are relevant in so far as the legislator has a discretio-

38 BVerfG, Beschluss der 3. Kammer des Ersten Senats vom 26. März 2014 - 1 BvR 3185/09 - Rn. (1-42), http://www.bverfg.de/e/rk20140326 1bvr318509.htm.

39 Para. 32.

40 BVerfG, Beschluss des Zweiten Senats vom 21. April 2015 - 2 BvR 1322/12 - Rn. (1-94), http://www .bverfg.de/e/rs20150421_2bvr132212.html, paras. 64, 65.

41 BVerfG, Beschluss der 2. Kammer des Ersten Senats vom 10. August 2017 - 1 BvR 1803/15 - Rn. (1-23), http://www.bverfg.de/e/rk20170810_1bvr180315.html, para. 19.

42 See for example the three judges decisions: 2BvR455/17; 2BvR1758/17, 2BvR965/15; 1BvR229/16.

43 BVerfG, Beschluss der 2. Kammer des Ersten Senats vom 18. Mai 2016 - 1 BvR 895/16 - Rn. (1-47), http://www.bverfg.de/e/rk20160518_1bvr089516.html. 
nary power for the implementation of EU law, that means that the legislator insofar is not determined by EU law.

In the three judges decision of September 6, 2016 44 (concerning the extradition of a person to United Kingdom and the issue whether the silence of the accused can be interpreted in his/her disadvantage) the primacy of EU law is confirmed but reference is made in the subsequent argumentation only to the constitutional identity concept.

In the judgement of May 31, $2016^{45}$ concerning the sampling of music excerpts the FCC states the violation of article 5.3 BL and remands the case back to be decided anew by the Federal Court of Justice (BGH) obliging it to interpret the provisions of the national law in conformity with the EU directive and to make an adequate balance of the various fundamental rights protected by EU law. When interpreting the copyright directive, the BGH shall adequately balance article $13.1 \mathrm{ChFR}$ which guarantees the freedom of art with article 17.2 ChFR which protects intellectual property. The FCC indirectly recognizes the application of the ChFR.

It shall be shortly mentioned that the FCC mentions, in its decision of January 23, $2017,{ }^{46}$ s. 53 second sentence of the Act on the Federal Central Register (BZRG) which refers to the ChFR.

\subsection{OTHER COURTS THAN THE FCC}

If we look at the Federal Court of Justice $(\mathrm{BGH})^{47}$, the Federal Social Court $^{48}$, the Federal Labor Court ${ }^{49}$, the Federal Administrative Court ${ }^{50}$ and the Federal Fiscal Court ${ }^{51}$ we find a relatively frequent reference to the ChFR. ${ }^{52}$ Often EU directives are interpreted by these courts in the light of the ChFR. The same takes place for the interpretation of ordinary national law if it is the implementation of EU directives. Often parallel reference is made to the ChFR and the BL. The Federal Social Court ${ }^{53}$ refers in particular to article 47.2 ChFR for the right to be heard by the tribunal (referring also to article 103.1 BL, article 6.1 of the Convention for the Protection of Human Rights and Fundamental Freedoms and the corresponding right in the Act on social jurisdiction

44 BVerfG, Beschluss der 2. Kammer des Zweiten Senats vom 06. September 2016 - 2 BvR 890/16 - Rn. (1-46), http://www.bverfg.de/e/rk20160906_2bvr089016.html.

45 BVerfG, Urteil des Ersten Senats vom 31. Mai 2016 - 1 BvR 1585/13 - Rn. (1-125), http://www.bverfg.de /e/rs20160531 1bvr158513.html.

46 BVerfG, Order of the Second Senate of 06 July 2010 - 2 BvR 2661/06 - paras. (1-116), http://www.bverfg.de /e/rs20100706_2bvr266106en.html.

47 The supreme federal court in civil and penal law matters; see Art. 133 and 135 GVG (Courts Constitution Act).

48 The supreme federal court in social matters; see Art. 38, 51 and 160 SGG (Act on Social Jurisdiction).

49 The supreme federal labor court; see Art. 40 and 72 ArbGG (Act on Labor Courts).

50 The supreme federal administrative court; see Art. 2 and 132 VwGO (Act on Administrative Jurisdiction).

51 The supreme federal court in fiscal matters; see Art. 62 and 115 FGO (Act on Fiscal Jurisdiction)

52 For the BGH see: I ZR115/16; I ZR162/10; IM ZR228/15; I ZR54/16- I ZR 59/13; I ZR139/15; 1StR447/14; I ZR255/14; I ZR188/16;I ZR19/16; I ZR 220/15; I ZR154/15; I ZR 174/ 14; I ZR 3/14; I ZR191/08; I ZR193/16; I ZR154/15-1StR32/13; X ZR146/11; 1 StR57/10; 5 StR532/16; 5 StR57/10; \% Str532/16; I ZR163/16; IV ZR141/16; 1 StR447/14;I ZR11/16.

53 B9SB60/14B; B1KR11/17B and many others. 
(s. $62 \mathrm{SGG})$ ). The Federal Labor Court ${ }^{54}$ refers to the ChFR in particular for the interpretation of German law determined by EU law, in particular by directives. The Federal Administrative Court ${ }^{55}$ discusses in various judgments the application of the ChFR denying this. The Federal Fiscal Court ${ }^{56}$ refers to the ChFR in particular for the right to be heard before the tribunal (article 47.2 ChFR).

\title{
6. CONCLUSION
}

The German Federal Constitutional Court has accepted the primacy of supranational over national ordinary and constitutional law. However, primacy is not accepted as the core elements of the Constitution are concerned. In the Lisbon Treaty decision the court has elaborated the concept of constitutional identity which is defined in accordance with the limits for constitutional reform established by article 79.3 BL. Human dignity (Art. 1.1 BL) as the supreme value of the German constitutional order as well as the basic structures of the State (Art. $20 \mathrm{BL}$ ) are protected by this disposition against modification or even elimination by constitutional reform and also against the impact of supranational law. The applicability of the Charter of Fundamental Rights of the EU according to its article 51 is also accepted by the FCC, however, the Court interprets this article in a stricter way than the CJEU. While the German text says that the Charter is applicable for the member States "exclusively when EU law is executed", the Charter applies, in the FCC's understanding, only if German law is" determined" by EU law. If human dignity is concerned in the case, the FCC does not refer to the Charter but applies Art. 1.1 BL. The identity concept prevails over EU law primacy.

The German FCC has consolidated in its rich jurisprudence related to the EC/EU the positive orientation of Germany towards European integration through the acceptance of the basic legal features of the supranational institutions but has maintained the own constitutional culture as expressed by the core elements of the Constitution. This field of constitutional identity is regarded as a basic feature of sovereignty which remains national and cannot be Europeanized. However, common legal thinking in Europe promotes the approximation of the basic constitutional concepts so that divergences between the various constitutional levels continuously disappear.

\author{
Prof. Dr. Dr.h.c. mult. Rainer Arnold \\ University of Regensburg \\ jean.monnet@gmx.de \\ Dipl.-Jur. Lukas Cerny \\ University of Regensburg \\ lukas.cerny@jura.uni-regensburg.de
}

\footnotetext{
1AZR79/12; 7AZR946/07; 8AZR501/14.

1B26.15; 10C24.14;6C12.16.

56 V R 51/16; V S 8/10; VI B 98/11; IX S 3/17.
} 